\title{
The Association between E-Services Web Portals Information Quality and ICT Competence in the Jordanian Universities
}

\author{
Sufian M Khwaldeh ${ }^{1}$, Issam Al-Hadid ${ }^{1}$, Ra'ed Masa'deh ${ }^{2}, \&$ Ala'aldin Alrowwad $^{3}$ \\ ${ }^{1}$ Business Information Technology (BIT) Department, The University of Jordan, Aqaba Branch, Jordan \\ ${ }^{2}$ School of Business, The University of Jordan, Amman, Jordan \\ ${ }^{3}$ Department of Business Management, The University of Jordan, Aqaba Branch, Jordan \\ Correspondence: Sufian M Khwaldeh, Business Information Technology (BIT) Department, The University of \\ Jordan, Aqaba Branch, Jordan. E-mail: skhwaldeh@gmail.com
}

Received: October 1, 2016

Accepted: January 31, 2017 Online Published: February 15, 2017

doi:10.5539/ass.v13n3p156

URL: http://dx.doi.org/10.5539/ass.v13n3p156

\begin{abstract}
The rapid growth of Internet has given extraordinary opportunities to organizations and business to provide services via the Internet (E-services). Moreover, E-services became a key aspect of any organization competitiveness. In Jordan, most of the universities provide different e-services portals to their students. This paper aims to investigate and explore the association between e-services web portals information quality and ICT competence in the Jordanian universities. The current research conducted by using survey questionnaires on a large population from Jordanian Universities. Specifically, 428post and undergraduate students answered the survey from different faculties at the Jordanian Universities. Results found a positive relationship between e-services web portals information quality and ICT competence. Results of T-test indicated that there is no significant difference in the relationship between information quality and ICT competence in the Jordanian universities due to gender and faculty type respectively; whereas the results as found a significant difference in the relationship between information quality and ICT competence due to university type. Also, results of ANOVA test indicated that there is no significant difference in the relationship between information quality and ICT competence in the Jordanian universities that can be attributed to academic year level, and academic degree level.
\end{abstract}

Keywords: E-services, Web Portals, Information Quality, ICT Competence, Jordan, T-test, ANOVA

\section{Introduction}

Student e-services are the collection of administrative processes that enable universities and academic organizations to provide services for their students. The main aim of students' e-services is to present all related educational data and information to students during their studies as well as after graduation. Therefore, it accumulates and integrates all educational content from different systems at the university and act as hub between these systems such as the financial system, academic and grading system, e-learning system or the LMS/LCMS, library service (Nedeva \& Zlatev, 2013). Such services became as standards within the educational e-services for university students (Sutarso \& Suharmadi, 2011). Academic organizations and universities offer such services to support and provide educational information to their students to ensure management issues handled and to satisfy students' needs such thing will ensure and meet quality requirements and educational, administrative needs for the university and the students. Moreover, the automation of these services will be handled efficiently and effectively (Masa'deh, \& Shannak, 2012) (Kim-Soon, Abd Rahman, \& Ahmed, 2014).

The use of e-service at the universities has brought changes to the business process and job roles and shifted some of the responsibilities form staff to students so they can perform different educational activities by the student themselves. This has resulted in reducing the universities workload and involvement in the process (Kim-Soon, Abd Rahman, \& Ahmed, 2014). Since the first time students e-service introduced and until now, the quality of student e-service remind questionable in terms if it meets the students requirements and if it satisfy their needs. Previous studies investigated this issue and identified several dimensions as criteria of e-service quality. However, there is an urgent need for a quality of e-service measurement tool and scale as it will help in improving the performance for the university and usability, user satisfaction and experience for students 
(Vratskikh et al., 2016) (Yang C. C., 2003).

According to Nedeva \& Zlatev (2013), previous research showed that bigger and richer business and organizations could provide better e-services and information to their users. This implies to richer universities compared to other universities with lower income and budget or even struggling ones when providing e-services to the students. Fei Yang (2006) reported that the cost of technology-supported educational systems is serious and critical challenge in developing countries and its educational institutions and universities although it is very important. Moreover, e-service portals are very expensive \& time consuming when it comes to development and maintenance (Bringula \& Basa, 2011). This research focuses on the Information Quality (IQ) aspect and dimension. Information quality defined by McKinney et al. (2002) as "users' perception of the quality of information presented on a Web site". Moreover, Information quality described as the ability of a collection of data or information to meet user requirements (Cappielloet et al., 2004) \& (Strong et al., 1997).

According to Cappielloet et al. (2004), data quality and information quality (DQ/IQ) is a multi-dimentional concept. According to Caro et al. (2006), there is a lack of research on the understanding of DQ/DI from the user perspective due to the different use, catagories and charactrestics of web portals. Moreover, the user has no control on the qaulity of data and information presented by the portal. The main aim of web portal from user perspective is to find and retrive data \& information that meet their expectations as the users determine the quality of the retrived data \& infromation (Wang \& Strong, 1996). This research aims to add a better clarity to this research area by examining the relationship between E-Services Web Portals Information Quality and ICT Competence in the Jordanian Universities due to demographic factors. The structure of this paper is as follows. Section 2 discusses the literature review and related work to the research. Section 3 describes the research methodology. Section 4 presents the data analysis and results. Section 5 gives further discussion of the findings and concludes the paper.

\section{Research Background}

\subsection{Research on E-service Quality of Website}

Several researchers consider the IT and its flexibility as an enabler to achieve the desired competitive advantages, considered as a strategic weapon, and as a crucial support to operational and strategic business processes (Alkalha et al., 2012; Almajali et al., 2016; Altamony et al. 2012; Shannak et al., 2010; Shannak et al., 2012; Masa'deh et al., 2016). According IBM (2010) e-service portals is "a single integrated, ubiquitous, and useful access to information (data), applications and people". Based on above definition, many researchers defined a student's portal at universities as a gate or place that brings all together student's information in an organized and coherent way that could have all or some of the student educational and academic, financial and personal information (Nedeva \& Zlatev, 2013; Abdulhamid \& Ismaila, 2010). Daigle \& Cuocco (2002) emphasised the importance of e-service portals adoption by universities as it will "improve productivity by increasing the speed and customizing the content of information provided to internal and external constituencies". Morover, the e-services portal will facilitate and improve information and knowledge communication, exchange and transfere among users (Masa'deh et al., 2015) (Kidwell, Vander Linde, \& Johnson, 2000).

E-services portals has enabled universities to automate its administrative process and more importantly to personalise educational information. Administrative process and services related to studetns includes Registration service; students status system (grades, attendance record, financial status, current schedule, withdraw from modules, pay/view tuition, drop or add modules, ... etc), e-learning gateway (class material and lecture notes), research databases (online library service, international library services) (Pena-Bandalaria, 2007). Moreover, Katz \& Associates (2002) as described e-services portals at universities as "The new, wonderful, and challenging aspect of Web management posed by portals is the idea of creating and managing information systems whose primary purpose is to sustain positive relationships between an institution's stakeholders and the institution have described the importance of such services". On a strategic level, e-services represent a huge chance to the universities in order to boost and improve its competitiveness' by leveraging research and innovation (Obeidat et al., 2016). This will put such universities on the map of a prestige's list of universities.

Dale (1999), Cox \& Dale (2002), Al Azmi et al. (2012) and Obeidat et al. (2012) emphasized the importance of e-service portals quality. As it will satisfy the end user and because of the quality of e-service portals provided by institution gives real indication about institution commitments to its users and customers. Moreover, users use the e-service portals to provide them with fast-personalized services. This has shifted the concept of user and customer's service to the concept of mass personalization services with emphasis on having a satisfaction on user experience that will reflects the on e-service portal usability. Several models have been proposed to measure quality factors such as the (e-SERVQUAL) proposed by Zeithaml (2002), this model focus on efficiency, 
fulfilment, reliability, privacy, responsiveness, compensation and contact. However, the compensation dimension is not applicable into university student e-service portals as it was-based on concepts of both e-service quality and retailing literate.

The (.comQ) model, developed by Wolfinbarger \& Gilly (2002). This model focused on reliability, customer service, website design and Privacy/security. The 6i model, developed by Btoush et al (2011), this model described the e-service characterstics. this model is devided into two states the first state focus on the Inform, Interact, Intercommunicate and Individualize. The second state of $6 \mathrm{i}$ model focus on the intigaration and invlovment. Loiacono et al. (2000) developed the WebQual model to measure a website quality. This model focus on informational fit to task, interaction, trust, response time, design, intuitiveness, visual appeal, innovativeness, flow, integrated communication, business and Substitutability. SITEQUAL (site quality) model, developed by Yoo and Donthu (2001). This model focused on ease of use, aesthetics design, processing speed, and security. However, the compensation dimension is not applicable into university student e-service portals as it was-based on concepts of both e-service quality and retailing literate.

\subsection{Situation in Jordan}

The first formal HE institution in Jordan was Jordan University, established in 1961-1962 (Jordan University, 2016). Since then, the number of HE institutions has increased to 30 universities. All the HE institutions fall under the supervision of the Ministry of Higher Education (MOHE). Moreover, the Jordanian government has opened the door for private sector participation in Jordanian HE. This step has led to 20 of the 30 universities in Jordan being privately owned (MOHE-Jordan, 2016).

The Hashemite Kingdom of Jordan is an Arab country located in the Middle East with almost no or little resource and considered a developing country (Khasawneh, 2015). According to Khasawneh (2015), Jordan adopted the use of ICT in all sectors including higher education institutions and universities as part of its strategy to overcome its lack of provision. Jordan has invested in higher education with the establishment of over 30 universities (Al-Sarayreh \& Al-Assaf, 2008).Many studies has addressed the quality factors of Jordanian universities websites and e-services portals such as the study conducted by Awwad (2006) which studied the quality factors of Jordanian universities websites; the study of Shaltoni et al. (2015) whom explored the students satisfaction with universities portals in developing countries. Moreover, Hasan conducted a Heuristic Evaluation of Three Jordanian Universities websites and before that, she evaluated the usability of nine Jordanian universities websites (Hasan, 2013). Allahawiah (2013) studied the Factors Affecting the Use of E-Services from User Perspectives and took Al-Balqa' Applied University website as case study where he explored the major factors affecting user's utilization of e-services offered by Al-Balqa Applied University such as Reliability; Responsiveness; Information quality; Usability; and Security. Alshamayleh et al. (2015) conducted a study on measuring the quality of e-services and its impact on student's satisfaction at Jordanian universities and proposed a model that examined the factors affecting the quality of e-services like responsiveness, Website design, reliability, ease of use, efficiency, availability and privacy.

Based on above, the adoption of the ICT and e-service in Jordanian universities considered as a strategic, urgent and radical step to overcome the shortage in provisions and infrastructure. Moreover, it is important for Jordanian universities to reach the optimum use of their students' e-services and make sure that e-services meet the students' requirements. Such goal requires studying information quality at the university web portals and ICT competence. The importance of this study comes from the fact that there is a need to study if there is any association between e-services web portals information quality and ICT competence in the Jordanian Universities. The results will highlight this area in a depth. It is important to note that most previous studies were targeting the university's website not the e-service portals. Moreover, they were targeting e-service web portals quality factors in general.

\subsection{Research on Information Quality E-Services Web Portals Information Quality}

Davis (1989) has developed the TAM model, which is suggesting that the determining factor of adopting information technology systems (including the web portals) is the user attitude toward usefulness and ease of use Based on above, the user attitude toward usefulness and ease of use of a web portal is based on his/her satisfaction of web portal qualities. According to Barnes \& Videgen (2005) the WebQual 4.0 model is divided into three dimentions and they are usability, information quality and service interaction. Morover, Tate et al (2007) have summerised the university web portal into 4 quality facoters, these factores are content, usability,service interaction qulity, and transaction quality and saftey.In their model, Barnes \& Videgen (2005) translated and discribed information quality fetor into the folowing items: accurate information, believable information, timely information, relevant information, easy to understand information, information at the right 
level of detail, and information in an appropriate Format. Based on above we can conclude that the information quality of a web portal is a determinants factor of user perceived usefulness and ease of use.

Several models have been proposed to measure information quality factors such as (PDQM), proposed by Caro et al. (2006), the PDQM is data model for web portals that focus upon the data user perspective taking into account the web data quality attributes and web portal functionalities as well. Redman (2000) grouped the data \& information quality from the user perspective in a web portal into privacy, Content, Quality of Values, Presentation, Improvement and Commitment. Moreover, Collins (2000) described the web portal software functions such as Data Points and Integration,Content management, Personalization, Presentation, Security, Search capabilities, Taxonomy, Help features, Process and action (workflow).According to Chen \& Chang (2010) \& Barnes \& Videgen (2005) the information quality can judges by how accurate information \& content is? from the user perspictive, how believable the information \&content is ? from the user perspictive, how timely the information \& content is? from the user perspictive, how relevant the information \& content is? from the user perspictive, how easy the information \& content to be understod from the user perspictive, how information at the right level of detail, and how information \& content showed from the user perspective in an appropriate Format.

According to Knight \& Burn (2005), Wang \& Strong (1996) summerised the informtion quality into 20 dimentions. the most imortant among them are:

- Accuracy(To which extent information \& content are correct and free of error such as (there is no spelling error or grammar error)),

- Relevancy(To which extent information \& content are applicable and helpful),

- Timeliness(To which extent information \& content are sufficiently up-to-date),

- Concise (To which extent information \& content are compactly represented without being overwhelming),

- Understandibilty(To which extent information \& content areunderstandable by the user ),

- The customisation and variaty of presintation(To which extent information \& content are taliored \& customised to be presented in different forms (text,.doc, .pdf, ...) and according to the user needs),

- Accessiblity (To which extent information \& content are available, or easily and quickly retrievable),

- Completenes (To which extent information \& content are not missing and is of sufficient breadth and depth)

The researchers have adapted these information qualities dimensions for the purpose of this research. See Table 5 .

\subsection{ICT Competences \& Web Portals}

The use of computers and mobile phones has increased over the years espcilly among the students. Oluwatobi \& Yemisi (2014) regarded demographic characteristics as well as their competence in information technology as critical factors when dealing with student e-services portals. Previous research showed that the level of experience in using computers and mobile phones would influence on user effort in using web portals such as making it easy to use and easy to learn (Smith, 2001). More importantly, a high level of ICT competence will reflect on the adaptability of a web portal for the users. Several studies such as (Park \& Chen, (2007); Lu \& Viehland , (2008); Abu-Al-Aish \& Love (2013); Callum, Jeffrey, \& Kinshuk, (2014)) confirmed the relationship between the adoption of information technology, perceived ease of use and ICT competence.

One of the important factors in ICT Competence when using student web portals is the ease of learning and the ease of using the web portal. According to Dennis et al (2009) ease of learning and ease of use are important factors related to the user experience principle that should be taken into account when designing user interface. Ease of learning is significant issue for inexperienced users and relevant to systems with a large user population (in our case are the students). Ease of use is significant issue for expert users (who are professional and competent in using ICT) which is very important in specialized systems (such as student web portal). According to Dennis et al. (2009) Sometimes ease of learning and use of use go hand in hand.According to Oluwatobi \& Yemisi (2014), ICT Skills and competence includes Word processing skills, Sending and receiving emails, Using a WWW search engine such as Google, Use of spreadsheet, PowerPoint design \& presentation, Downloading a file from the internet. Based on what Oluwatobi \& Yemisi (2014) stated, four items developed in order gain more information about jordain university students ICT competence. See Table 5.

\section{Research Methodology}

The major elements of this research are established based on preceding literature, either theoretically or empirically. This section provides the methodology applied in this study. The methodology includes the research 
theoretical framework, procedural definitions, research hypotheses, research type and scale, research population and sample, besides data collection and analysis procedures. The reliability and validity of the study are also provided. As this research is deductive and quantitative in its nature, one of the important characteristic of deduction is the need to operationalize the variables of the study in a way that facilitate the measurement of facts quantitatively (Saunders, Lewis, \& Thornh, 2009). Indeed, the variable of information quality was adapted from Wang \& Strong (1996) and validated by Knight \& Burn (2005); and ICT competence was identified from Oluwatobi \& Yemisi (2014).

\subsection{Research Theoretical Model}

This study used variables that are common in e-service web portals literature. By reviewing the literature, it was noticed that there is a need to examine if there are a relationship between information quality provided by the e-service web portals and ICT student's competence due to demographic factors. Figure (1) displays the research's proposed model.

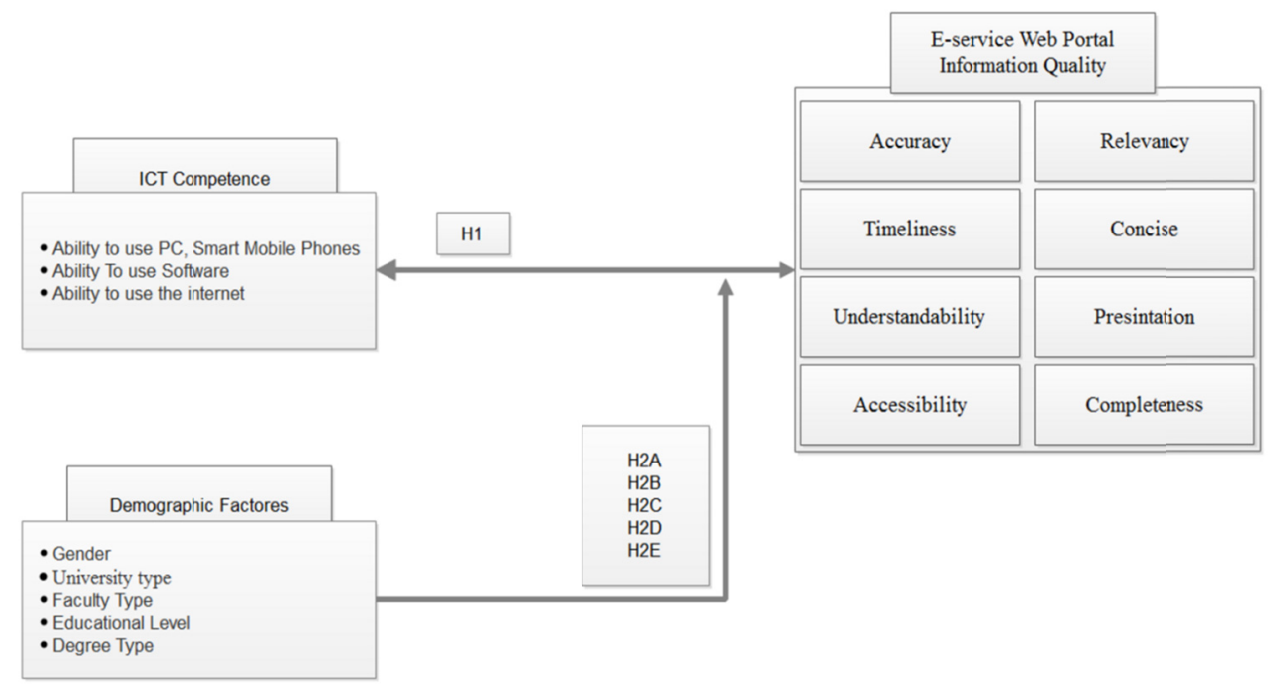

Figure 1. The Research Model

\subsection{Research Hypotheses}

In order to test the relationship between information quality and ICT competence; the study is hypothesized as follows:

\subsubsection{The Main Research Hypotheses}

H1: There is a statistically significant relationship between information quality and ICT competence in the Jordanian universities.

$\mathrm{H} 2$ : There is a significant difference in the relationship between information quality and ICT competence in the Jordanian universities due to demographic characteristics.

\subsubsection{The Research Sub-Hypotheses}

$\mathrm{H} 2 \mathrm{~A}$ : There is a significant difference in the relationship between information quality and ICT competence in the Jordanian universities due to gender.

H2B: There is a significant difference in the relationship between information quality and ICT competence in the Jordanian universities due to university type.

$\mathrm{H} 2 \mathrm{C}$ : There is a significant difference in the relationship between information quality and ICT competence in the Jordanian universities due to faculty type.

H2D: There is a significant difference in the relationship between information quality and ICT competence in the Jordanian universities due to academic year level.

H2E: There is a significant difference in the relationship between information quality and ICT competence in the Jordanian universities due to academic degree level.

\subsection{Population and Sample}

Data should be collected from the people that can provide the correct answers to solve the problem (Sekaran, 
2003 ) and represent the whole people, events or objects the researcher want to study. Therefore, the population of this study consists of students who are currently enrolled for undergraduate and postgraduate studies and from wide range different backgrounds such as Business Information Technology, Computer Information Technology, Management Information Technology, Nursing, Management, Accounting, Law, and Education \& Social Studies. Indeed, the researchers have chosen undergraduate and postgraduate students from all faculties. In addition, the current research data conducted by using a questionnaire. This technique is less expensive and consumes less time than other methods such as interviews; and covers a wider geographical area. As a result, the researchers used this method of data collection. Indeed, by using a drop and collect method to thousands of students, 428questionnaire were answered, which is adequate for statistical analysis, based on (Krejcie \& Morgan, 1970), and (Pallant, 2005).

\section{Data Analysis and Results}

Descriptive analysis used to describe the characteristic of sample and the respondent to the questionnaires. Correlation coefficients used to determine the relationship between the items for both variables. In addition, a Pearson correlation matrix, T-test and ANOVA test employed to test the hypotheses.

\subsection{Reliability and Validity}

According to (Sekaran \& Roger 2013), it is important to make sure that the instrument developed to measure a particular concept is accurately measuring the variable and is actually measuring the concept that it is supposed to measure in the research. Indeed, reliability analysis is related to the assessment of the degree of consistency between multiple measurements of a variable, whereas validity analysis refers to the degree to which a scale or set of measures accurately represents the construct (Hair et al., 1998). The reliability of the instrument measured by the Cronbach's alpha coefficient. Further, some scholars (e.g. Bagozzi \& Yi, 1988) suggested that the values of all indicators or dimensional scales should be above the recommended value of 0.60 . However, the Cronbach's alpha for current research variables were 0.92 and 0.87 for information quality and ICT competence respectively. Convergent validity refers to the degree to which items or measures correlated with each other to measure the same construct. Therefore, higher correlation shows that the scale is assessing its aimed construct. The closer the values are to 1 the more highly correlated the items are, and specifically the individual item reliability is recommended to be greater than 0.50 (Fornell \& Larcker, 1981)(Bagozzi \& Yi, 1988). Table 1 and Table 2 display the correlations between the research items.

Table 1. Correlations between the Information Quality (IQ) Items

\begin{tabular}{ccccccccc}
\hline IQ Items & IQ1 & IQ2 & IQ3 & IQ4 & IQ5 & IQ6 & IQ7 & IQ8 \\
\hline IQ1 & 1.000 & & & & & & & \\
IQ2 & 0.604 & 1.000 & & & & & & \\
IQ3 & 0.536 & 0.578 & 1.000 & & & & & \\
IQ4 & 0.502 & 0.584 & 0.522 & 1.000 & & & & \\
IQ5 & 0.519 & 0.489 & 0.537 & 0.563 & 1.000 & & & \\
IQ6 & 0.483 & 0.553 & 0.591 & 0.521 & 0.549 & 1.000 & & \\
IQ7 & 0.463 & 0.457 & 0.564 & 0.505 & 0.534 & 0.582 & 1.000 & \\
IQ8 & 0.441 & 0.486 & 0.595 & 0.522 & 0.583 & 0.547 & 0.532 & 1.000 \\
\hline
\end{tabular}

Table 2. Correlations between the ICT Competence (IC) Items

\begin{tabular}{ccccc}
\hline IC Items & IC1 1 & IC2 & IC3 & IC4 \\
\hline IC1 & 1.000 & & & \\
IC2 & 0.624 & 1.000 & & \\
IC3 & 0.532 & 0.621 & 1.000 & 1.000 \\
IC4 & 0.560 & 0.611 & 0.595 & \\
\hline
\end{tabular}

As shown above from both Tables 1 and 2 that most of the values were close to 0.5 , which indicate a positive correlation between items. This leads to a higher level of convergent validity.

\subsection{Respondents Demographic Profile}

As showed in Table 3, the demographic profile of the respondents for this study revealed that they are typically males, most of them in their fourth year level in the scientific faculties, and $84.3 \%$ of them in their bachelor level. 
Table 3. Respondents Demographic Profile based on the Researchers' Analysis

\begin{tabular}{|c|c|c|c|}
\hline \multicolumn{2}{|c|}{ Category } & \multirow{2}{*}{$\begin{array}{c}\text { Frequency } \\
226\end{array}$} & \multirow{2}{*}{$\frac{\text { Percentage } \%}{52.8}$} \\
\hline Gender & Male & & \\
\hline & Female & 202 & 47.2 \\
\hline & Total & 428 & 100 \\
\hline \multirow[t]{3}{*}{ University type } & Public & 229 & 53.5 \\
\hline & Private & 199 & 46.5 \\
\hline & Total & 428 & 100 \\
\hline \multirow[t]{3}{*}{ Faculty type } & Scientific & 267 & 62.4 \\
\hline & Social Sciences & 161 & 37.6 \\
\hline & Total & 428 & 100 \\
\hline \multirow[t]{6}{*}{ Educational Level } & Year 1 & 68 & 15.9 \\
\hline & Year 2 & 75 & 17.5 \\
\hline & Year 3 & 92 & 21.5 \\
\hline & Year 4 & 156 & 36.3 \\
\hline & Year 5 and more & 37 & 8.6 \\
\hline & Total & 428 & 100 \\
\hline \multirow[t]{4}{*}{ Degree type } & Bachelor & 361 & 84.3 \\
\hline & Master & 39 & 9.1 \\
\hline & Doctorate & 28 & 6.6 \\
\hline & Total & 428 & 100 \\
\hline
\end{tabular}

\subsection{Descriptive Analysis}

In order to describe the responses and thus the attitude of the respondents toward each question they asked in the survey, the mean and the standard deviation estimated. While the mean shows the central tendency of the data, the standard deviation measures the dispersion which offers an index of the spread or variability in the data (Sekaran, 2003) \& (Sekaran \& Roger, 2013). In other words, a small standard deviation for a set of values reveals that these values clustered closely about the mean or located close to it; a large standard deviation indicates the opposite. Table 4 shows the overall mean and standard deviation of the research variables.

Table 4. Mean and Standard Deviation of the Study's Variables

\begin{tabular}{ccc}
\hline Variables & Mean & Std. Deviation \\
\hline Information Quality & 3.3952 & 0.96058 \\
ICT Competence & 4.1793 & 0.94156 \\
\hline
\end{tabular}

As presented in Table 4, data analysis results have shown that information quality among students applied moderately at the Jordanian universities in which the mean score is 3.3952. This is an indicator on the importance of the information quality toward the student e-service web portals of the Jordanian universities and the essential role that they could play in using the students' e-service web portal. Furthermore, data analysis results have revealed that ICT competence is applied to a great extent in which the mean score is 4.1793. This high level of presentation denotes a positive attitude regarding students' access devices. This sturdily advocates that Jordanian universities are currently engaging in information technology and mobile application activities with their students.

\subsubsection{Research Variables}

Table 5 demonstrates the mean scores for information quality and ICT competence:

Table 5. Mean and Standard Deviation for the Research Variables

\begin{tabular}{lll}
\hline Information Quality & Mean & Std. Dev. \\
\hline $\begin{array}{l}\text { Student E-service Portal at my university provides accurate information \& content regarding my } \\
\text { academic status }\end{array}$ & 3.46 & 1.182 \\
$\begin{array}{l}\text { Student E-service Portal at my university provides relevant information \& content about my } \\
\text { academic status }\end{array}$ & 3.41 & 1.212 \\
\hline
\end{tabular}




\begin{tabular}{|c|c|c|}
\hline $\begin{array}{l}\text { Student E-service Portal at my university provides up-to-date information \& content regarding my } \\
\text { academic status }\end{array}$ & 3.28 & 1.245 \\
\hline $\begin{array}{l}\text { Student E-service Portal at my university provides me the right level of detail of information \& } \\
\text { content regarding my academic status }\end{array}$ & 3.48 & 1.192 \\
\hline $\begin{array}{l}\text { Student E-service Portal at my university provides me with understandable information \& content (I } \\
\text { can understand easily different types of information about my status such as academic, } \\
\text { financial,...etc) }\end{array}$ & 3.35 & 1.212 \\
\hline $\begin{array}{l}\text { I can view my academic information and content using Student E-service Portal at my university in } \\
\text { different ways (presenting information and content in an appropriate format) }\end{array}$ & 3.48 & 1.144 \\
\hline $\begin{array}{l}\text { Student E-service Portal at my university provides a complete information \& content regarding my } \\
\text { academic status }\end{array}$ & 3.25 & 1.230 \\
\hline $\begin{array}{l}\text { Student E-service Portal at my university provides me with accessibility to my information \& } \\
\text { content regarding my academic status }\end{array}$ & 3.45 & 1.222 \\
\hline ICT Competence & Mean & Std. Dev. \\
\hline I can Browse the Internet, websites using my PC, Laptop, Smart phone or Tablet & 4.24 & 1.141 \\
\hline I can use search engines like Google, Bing and Yahoo & 4.34 & 1.016 \\
\hline $\begin{array}{l}\text { I can Use my PC and/or Laptop to perform simple tasks like (Copy, Cut and paste, use word } \\
\text { processing, spreadsheets, PowerPoint, Download \& upload files) }\end{array}$ & 4.23 & 1.061 \\
\hline $\begin{array}{l}\text { I can Use my Smart phone and/or Tablet to perform simple tasks like (Copy, Cut and paste, use word } \\
\text { processing, spreadsheets, PowerPoint, Download \& upload files) }\end{array}$ & 3.90 & 1.232 \\
\hline
\end{tabular}

\subsection{Hypothesis Testing Results}

\subsubsection{Hypothesis 1}

H1: There is a statistically significant relationship between information quality and ICT competence in the Jordanian universities.

The purpose of this study was to investigate the relationship between information quality and ICT competence in the Jordanian universities. Thus, a Pearson correlation matrix was conducted, Table 6, and showed a positive relationship $(\mathrm{p}=0.489)$ between information quality and ICT competence.

Table 6. A Pearson Correlation between Information Quality (IQ) and ICT Competence (IC)

\begin{tabular}{|c|c|c|c|}
\hline & & IQ & $\mathrm{IC}$ \\
\hline \multirow{3}{*}{ IQ } & Pearson Correlation & 1 & $0.489 * *$ \\
\hline & Sig. (2-tailed) & & 0.000 \\
\hline & $\mathrm{N}$ & 428 & 428 \\
\hline \multirow{3}{*}{$\mathrm{IC}$} & Pearson Correlation & $0.489 * *$ & 1 \\
\hline & Sig. (2-tailed) & 0.000 & \\
\hline & $\mathrm{N}$ & 428 & 428 \\
\hline
\end{tabular}

\subsubsection{Hypothesis 2}

Hypotheses H2A, H2B, H2C, H2D, and H2E argued that there is a significant difference in the relationship between information quality and ICT competence in the Jordanian universities due to gender, university type, faculty type, academic year level, and academic degree level respectively. Independent Samples T-test was employed in order to investigate if there any significant differences in the relationship between information quality and ICT competence that can be attributed to gender, university type, and faculty type. Also, ANOVA test was employed to examine if there any significant differences in relationship between information quality and ICT competence that can be attributed to academic year level, and academic degree level.

Results of T-test, shown in Tables 7 and 9, indicated that there is no significant difference in the relationship between information quality and ICT competence in the Jordanian universities that can be attributed to gender and faculty type respectively; while the results as indicated in Table 8 found a significant difference in the relationship between information quality and ICT competence due to university type. In addition, results of ANOVA test, shown in Table 10 and Table 11, indicated that there is no significant difference in the relationship between information quality and ICT competence in the Jordanian universities in favor of academic year level, and academic degree level. 
Table 7. T-test of the Difference in the Relationship between Information Quality and ICT Competence in the Jordanian Universities Due to Gender

\begin{tabular}{|c|c|c|c|c|c|c|c|c|c|}
\hline \multirow{2}{*}{ Variables } & \multicolumn{3}{|c|}{ Male } & \multicolumn{3}{|c|}{ Female } & \multirow{2}{*}{$\mathrm{T}$} & \multirow{2}{*}{ df } & \multirow{2}{*}{ Sig. } \\
\hline & $\mathrm{N}$ & Mean & Std. Dev. & $\mathrm{N}$ & Mean & Std. Dev. & & & \\
\hline $\begin{array}{c}\text { IQ \& ICT } \\
\text { Competence }\end{array}$ & 226 & 3.3955 & 1.00543 & 202 & 3.3948 & 0.91027 & 0.007 & 425.927 & 0.994 \\
\hline
\end{tabular}

Table 8. T-test of the Difference in the Relationship between Information Quality and ICT Competence in the Jordanian Universities Due to University Type

\begin{tabular}{|c|c|c|c|c|c|c|c|c|c|}
\hline \multirow{2}{*}{ Variables } & \multicolumn{3}{|c|}{ Public University } & \multicolumn{3}{|c|}{ Private University } & \multirow{2}{*}{$\mathrm{T}$} & \multirow{2}{*}{ df } & \multirow{2}{*}{ Sig. } \\
\hline & $\mathrm{N}$ & Mean & Std. Dev. & $\mathrm{N}$ & Mean & Std. Dev. & & & \\
\hline $\begin{array}{c}\text { IQ \& ICT } \\
\text { Competence }\end{array}$ & 229 & 3.1796 & 0.91723 & 199 & 3.6432 & 0.95159 & 5.112 & 412.996 & 0.000 \\
\hline
\end{tabular}

Table 9. T-test of the Difference in the Relationship between Information Quality and ICT Competence in the Jordanian Universities Due to Faculty Type

\begin{tabular}{|c|c|c|c|c|c|c|c|c|c|}
\hline \multirow{2}{*}{ Variables } & \multicolumn{3}{|c|}{ Scientific Faculty } & \multicolumn{3}{|c|}{ Social Science Faculty } & \multirow{2}{*}{$\mathrm{T}$} & \multirow{2}{*}{ df } & \multirow{2}{*}{ Sig. } \\
\hline & $\mathrm{N}$ & Mean & Std. Dev. & $\mathrm{N}$ & Mean & Std. Dev. & & & \\
\hline $\begin{array}{c}\text { IQ \& ICT } \\
\text { Competence }\end{array}$ & 267 & 3.4490 & 0.96138 & 161 & 3.3059 & 0.95555 & 1.497 & 338.970 & 0.135 \\
\hline
\end{tabular}

Table 10. ANOVA Analysis of the Difference in the Relationship between Information Quality and ICT Competence in the Jordanian Universities due to Academic Year Level

\begin{tabular}{|c|c|c|c|c|c|c|}
\hline Variables & & Sum of Squares & Df & Mean Square & $\mathrm{F}$ & Sig. \\
\hline \multirow{3}{*}{$\begin{array}{c}\text { IQ \& ICT } \\
\text { Competence }\end{array}$} & Between Groups & 4.593 & 4 & 1.148 & 1.247 & 0.290 \\
\hline & Within Groups & 389.405 & 423 & 0.921 & & \\
\hline & Total & 393.998 & 427 & & & \\
\hline
\end{tabular}

Table 11. ANOVA Analysis of the Difference in the Relationship between Information Quality and ICT Competence in the Jordanian Universities due to Academic Degree Level

\begin{tabular}{|c|c|c|c|c|c|c|}
\hline Variables & & Sum of Squares & Df & Mean Square & $\mathrm{F}$ & Sig. \\
\hline \multirow{3}{*}{$\begin{array}{c}\text { IQ \& ICT } \\
\text { Competence }\end{array}$} & Between Groups & 3.929 & 2 & 1.964 & 2.140 & 0.119 \\
\hline & Within Groups & 390.069 & 425 & 0.918 & & \\
\hline & Total & 393.998 & 427 & & & \\
\hline
\end{tabular}

\section{Discussion and Conclusions}

The primary motivation of this research is to examine the relationship between e-services Web portals information quality and ICT competence in the Jordanian Universities. The population of this study consists of under and postgraduates' students from scientific and social sciences faculties of public and private universities located in Jordan. After analyzing the respondents' demographic profile, it revealed that they are typically males, most of them in their fourth year level in the scientific faculties, and $84.3 \%$ of them in their bachelor level.

The proposed model has two main hypotheses (H1 and H2). The first hypothesis claims that there is a statistically significant relationship between information quality and ICT competence in the Jordanian universities. On the other hand, the second hypothesis with its sub hypotheses (H2A,H2B,H2C,H2D, and H2E) states that there is a significant difference in the relationship between information quality and ICT competence in the Jordanian universities due to demographic characteristics (moderate variables: gender, university type, faculty type, academic year level, and academic degree level). Before testing the proposed hypotheses, it was important to measure the consistency between the measured variables and how accurately they represent the proposed construct. For this purpose, the reliability and the convergent validity for both variables (e-services Web portals information quality and ICT competence) were approved. Cronbach's alpha coefficient and the correlation between the variables showed satisfactory results.

In order to test the hypotheses, a Pearson correlation matrix, T-test and ANOVA, were used. The main hypothesis H1 was analyzed. The result shown in table6indicated that there was a positive relationship $(p=0.489)$ and 
change in the same direction between information quality and ICT competence. Hypotheses H2A, H2B, H2C, $\mathrm{H} 2 \mathrm{D}$, and H2E stated that there were significant differences in the relationship between information quality and ICT competence in the Jordanian universities due to gender, university type, faculty type, academic year level, and academic degree level, respectively. By using T-test analysis, shown in Tables7 and 9, the current research found that there is no significant difference in the relationship between information quality and ICT competence in the Jordanian universities that can due to gender and faculty type; whilst the results as indicated in Table 8 found a significant difference in the relationship between information quality and ICT competence in favor of university type. Also, results of ANOVA test, shown in Table 10 and Table 11, found that there is no significant difference in the relationship between information quality and ICT competence in the Jordanian universities attributed to academic year level, and academic degree level respectively.

Table 8 found a significant difference in the relationship between information quality and ICT competence in favor of the private universities due to higher mean (3.6432) compared to the public universities mean (3.1796). This due to the fact that the Ministry of higher education and the accreditation and quality assurance commission for higher education institutions in Jordan draw more attention on the services and programs provided by the private universities in Jordan. Moreover, this proves the real intentions of the Private universities in competing with public universities in terms of providing better information quality on their web portals compared to the public universities in Jordan. The researchers reviewed the private and public universities compulsory courses and found that private universities put more focus on the ICT skill promoting among their students compared to the public universities in Jordan.

However, there are some limitations of the study. The researchers would like to note that this research is limited to the Jordanian context. Thus, this raises inquiries regarding the generalizability to other cultures and different contexts. Consequently, further research is needed with regards to several countries since this would help to advance understanding of the e-services Web portals information quality and ICT competence issues and the conditions and outcomes of achieving it from different nationwide origins in different contexts. Moreover, the responded sample size of this study is believed to be very small compared to the real number of under and postgraduate students in Jordanian universities as the total enrolled numbers in the academic year 2014-2015 were (195688) students for the public and (71008) students for the private universities making the total of (267489) students. According to Aguinis et al (2014), it is difficult to find significant relationships from the data. This is to say that although the response rate of this study was sufficient for the condition of statistical analysis, the percentage of those who did not respond was still observable. In other words, even though the research results could be representative, it is reasonable to be watchful in its generalization. Consequently, to increase statistical validity, then further research should consider higher response rates. Another limitation is that the proposed conceptual model is based on the cross-sectional data from Jordanian universities. Therefore, longitudinal investigations are preferred for better implications. Also, although this paper investigated several hypotheses and offered empirical support for the acceptance and refusal of some of these hypotheses; more generalizations on the application of the theoretical premises that developed in building the research model will be needed. This is to say that a more generalized research model that compensate the current research limitations by adding further impacting variables to the model and obtain a more representative sample from different sectors will be required. Finally, other factors that may affect the level of e-services can be assessed in future research.

To sum up, this research serves as a good start to study other factors such as web portal design; this will highlight the User Experience (UX) and Usability of the used e-services web portals at the Jordanian universities moreover, this will highlight the needs and user experience for the disabled users such as the deaf and the blind (Khwaldeh \& Shah, 2010). This includes studying and evaluating web portal appearance, aesthetics, the consistency in web portal design, the security and privacy issues, portability and satisfaction. Moreover, this study will come in use when conducting a heuristic evaluation and comparison between Jordanian universities e-services web portals for student and staff. This comparison includes educational services for student and academics. Moreover, this could be used in terms of comparing services to the staff at these universities. Finally, the research model in this study could be used to conduct similar research on e-services web portals information quality and ICT competence in the Jordanian universities from the staff perspective. Such research will complement this research and will give a clear idea about the status of e-services web portals information quality for the staff as well as current idea about the ICT competences among Jordanian universities staff.

\section{References}

Abdulhamid, S. M., \& Ismaila, I. (2010). Design Evaluation Of Some Nigerian University Portals: A Programmers Point Of View. Computer Science And Telecommunications (Gesj), 5(28), 21-28. Retrieved 
From Https://Arxiv.Org/Ftp/Arxiv/Papers/1402/1402.1241.Pdf

Abu-Al-Aish, A., \& Love, S. (2013). Factors Influencing Students' Acceptance of M-Learning: An Investigation in Higher Education. The International Review of Research in Open and Distributed Learning, 14(5). https://doi.org/10.19173/irrodl.v14i5.1631

Aguinis, H., \& Edwards, J. (2014). Methodological Wishes for the Next Decade and How to Make Wishes Come True. Journal of Management Studies, 51, 143-174. https://doi.org/10.1111/joms.12058

Al Azmi, N., Al-Lozi, M., Al Zu'bi, Z., \& Dahiyat, S. (2012). Patients Attitudes toward Service Quality and its Impact on their Satisfaction in Physical Therapy in KSA Hospitals. European Journal of Social Sciences, 34(2), 300-314.

Alkalha, Z., Al-Zu'bi, Z., Al-Dmour, H., Alshurideh, M., \& Masa'deh, R. (2012). Investigating the Effects of Human Resource Policies on Organizational Performance: An Empirical Study on Commercial Banks Operating in Jordan. European Journal of Economics, Finance and Administrative Sciences(51), 44-64.

Allahawiah, S. R. (2013). Factors Affecting the Use of E-Services from User . Journal of Management Research Perspectives: A Case Study of Al-Balqa'Applied University, 5(2), 45-64. doi:10.5296/jmr.v5i2.2951

Almajali, D., Masa'deh, R., \& Tarhini, A. (2016). Antecedents of ERP Systems Implementation Success: A Study on Jordanian Healthcare Sector. Journal of Enterprise Information Management, 29(4), 549-565. https://doi.org/10.1108/JEIM-03-2015-0024

Al-Sarayreh, K., \& Al-Assaf, L. (2008). Investigating Total Quality Management in Higher Education Institutions. Arab Journal for Quality Assurance in Higher Education, 1(1).

Alshamayleh, H., Aljaafreh, R., Aljaafreh, A., \& Albadayneh, D. (2015). Measuring the Quality of E-Services and Its Impact on Students Satisfaction at Jordanian Universities. Journal of Theoretical and Applied Information Technology, 74(3), 274-285.

Altamony, H., Masa'deh, R., Alshurideh, M., \& Obeidat, B. (2012). Information Systems for Competitive Advantage: Implementation of an Organisational Strategic Management Process. the 18th IBIMA Conference on Innovation and Sustainable Economic Competitive Advantage: From Regional Development to World Economic, (pp. 583-592). Istanbul, Turkey.

Awwad, M. (2006). Website Quality Factors from Jordanian Universities Students' Viewpoint. Jordan Journal of Business Administration, 2(1), 147-161.

Bagozzi, R., \& Yi, Y. (1988). On the Evaluation of Structural Equation Models. Journal of the Academy of Marketing Science, 16(1), 74-94. https://doi.org/10.1007/BF02723327

Barnes, S., \& Videgen, R. (2005). Data Triangulation in Action: Using Comment Analysis to Refine Web Quality Metrics. 13th European Conference on Information System (pp. 92-103). Regensburg: Germany.

Bringula, R. P., \& Basa, R. S. (2011). Factors Affecting Faculty Web Portal Usability. Educational Technology \& Society, 14(4), 253-265.

Btoush, H. M., Qteishat, M., Siddiqi, J., \& Akhgar, B. (2011). Users'Evaluation of Public E- Services: Jordanian context. The 2011 world congress in computer science computer engineering and applied computing. Las Vegas; Nevada, USA.

Callum, K. M., Jeffrey, L., \& Kinshuk. (2014). Factors Impacting Teachers' Adoption of Mobile Learning. Journal of Information Technology Education: Research, 13, 141-162. Retrieved from http://www.jite.org/documents/Vol13/JITEv13ResearchP141-162MacCallum0455.pdf

Cappielloet, C., Francalanci, C., \& Pernici, B. (2004). Data Quality Assessment from the User's Perspective. International Workshop on Information Quality in Information Systems (IQIS2004) (pp. 68-73). Paris: ACM.

Caro , A., Calero, C., Caballero, I., \& Piattini, M. (2006). Towards a Data Quality Model for Web Portals. The Second International Conference on Web Information Systems and Technologies (WEBIST 2006), (pp. 325-331). Setúbal, Portugal.

Chen, L.-S., \& Chang, P.-C. (2010). Identifying Crucial Website Quality Factors of Virtual Communities. The International MultiConference of Engineers and Computer Scientists 2010 (pp. 487-492). Kowloon, Hong Kong: Newswood Limited.

Collins, H. (2000). Corporate Portals: Revolutionizing Information Access to Increase Productivity and Drive the 
Bottom Line. AMACOM.

Cox, J., \& Dale, B. G. (2002). Key Quality Factors in Web Site Design and Use: An Examination. International $\begin{array}{lllll}\text { Journal of Quality \& Reliability } & \text { Management, } & \text { 19(7), }\end{array}$ http://dx.doi.org/10.1108/02656710210434784

Daigle, S. L., \& Cuocco, P. M. (2002). 'Portal Technology Opportunities, Obstacles, and Options: A View from the California State University' . In Web Portals and Higher Education,Technologies to Make IT Personal. In R. N. Katz, \& \&. Associates, Web Portals and Higher Education Technologies to Make IT Personal (pp. 109-123). Jossey-Bass, A Wiley Company.

Dale, B. G. (1999). Managing Quality (3rd ed.). Oxford: Blackwell Publishers.

Davis, F. D. (1989). Perceived Usefulness, Perceived Ease of Use, and User Acceptance of Information Technology. MIS Quarterly, 13(3), 319-340. https://doi.org/10.2307/249008

Dennis, A., Wixom, B. H., \& Tegarden, D. (2009). Systems Analysis and Design with UML Version 2.0: An Object-Oriented Approach. John Wiley \& Sons.

Fei Yang, J. (2006). The Discussion of Media Selection and Accessible Equity in Distance Education. Journal of American Academy of Business, 10(1), 126-130.

Fornell, C., \& Larcker, D. F. (1981). Evaluating Structural Equation Models with Unobservable Variables and Measurement Error. Journal of Marketing Research (JMR), 18(1), 39-50. https://doi.org/10.2307/3151312

Hair, J., Anderson, R., Tatham, R., \& Black, W. (1998). Multivariate Data Analysis. New Jersey: Prentice-Hall International Inc.

Hasan, L. (2013). Heuristic Evaluation of Three Jordanian University Websites. Informatics in Education, 12(2), 231-251.

Hasan, L., \& Abuelrub, E. (2011). Assessing the Quality of Web Sites. Applied Computing and Informatics, 9 , 11-29. https://doi.org/10.1016/j.aci.2009.03.001

IBM Global Education Industry. (2000). Higher Education Portals: Presenting Your Institution to the World. IBM.

Jordan University. (2016). Jordan University. Retrieved from Jordan University: www.Ju.edu.jo

Katz, R. N., \& Associates. (2002). Web Portals and Higher Education: Technologies to Make IT Personal. Jossey-Bass, A Wiley Company. Reprinted by permission of John Wiley \& Sons.

Khasawneh, M. (2015). Factors Influence e-Learning Utilization in Jordanian Universities - Academic Staff Perspectives. 4th International Conference on Leadership, Technology, Innovation and Business Management (ICLTIBM-2015) (pp. 170-180). Istanbul : Elsevier Ltd. https://doi.org/10.1016/j.sbspro.2015.11.356

Khwaldeh, S., \& Shah, M. (2010). The adaptability of an open source learning management system for deaf children in Jordan. The 2nd IEEE International Conference on Information Management and Engineering (ICIME), 2010 (pp. 34-39 ). Beijing, China: IEEE. https://doi.org/10.1109/ICIME.2010.5477480

Kidwell, J., Vander Linde, K., \& Johnson, S. (2000). Applying Corporate Knowledge Management Practices in Higher Education. Educause Quarterly, pp. 28-33.

Kim-Soon, N., Abd Rahman, \& Ahmed, M. (2014). E-Service Quality in Higher Education and Frequency of Use of the Service. International Education Studies, 7(3). doi:10.5539/ies.v7n3p1

Knight, S.-a., \& Burn , J. (2005). Developing a Framework for Assessing Information Quality on the World Wide Web. Informing Science Journal, 8(5), 159-172.

Krejcie, R. V., \& Morgan, D. W. (1970). Determining Sample Size for Research Activities. Education and Psychological Measurement, 30, 607-610. https://doi.org/10.1177/001316447003000308

Loiacono, E. T., Watson, R. T., \& Goodhue, D. L. (2000). WebQual ${ }^{\text {TM. }}$ A Measure of Web Site Quality. Georgia: University of Georgia.

Lu, X., \& Viehland, D. (2008). Factors Influencing the Adoption of Mobile Learning. ACLS 2008, (p. 56).

Masa'deh, R., Obeidat, B., \& Tarhini, A. (2016). A Jordanian Empirical Study of the Associations among Transformational Leadership, Transactional Leadership, Knowledge Sharing, Job Performance, and Firm Performance: A Structural Equation Modelling Approach. Journal of Management Development, 35(5), 
681-705.

Masa'deh, R., Tayeh, M., \& Al-Jarrah, I. M. (2015). Accounting vs. Market-based Measures of Firm Performance Related to Information Technology Investments. International Review of Social Sciences and Humanities, 9(1), 129-145. https://doi.org/10.1108/JMD-09-2015-0134

Masa'deh, R., \& Shannak, R. (2012). Intermediary Effects of Knowledge Management Strategy and Learning Orientation on Strategic Alignment and Firm Performance. Research Journal of International Studies, 24, 112-128.

McKinney, V., Yoon, K., \& Zahedi, F. (2002). The measurement of Webcustomer satisfaction: an expectation and disconfirmation approach. Information Systems Research, 296. https://doi.org/10.1287/isre.13.3.296.76

Ministery of Higher Education - Jordan. (2016). MOHE Universities. Retrieved from MOHE : www.mohe.gov.jo

Nedeva, V., \& Zlatev, Z. (2013). Quality of the Services Provided By a University Web Portal. Applied Researches in Technics, Technologies and Education, 1(3), 173-180.

Obeidat, B., Al-Suradi, M., \& Tarhini, A. (2016). The Impact of Knowledge Management on Innovation: An Empirical Study on Jordanian Consultancy Firms. Management Research Review, 39(10), 1214-1238. https://doi.org/10.1108/MRR-09-2015-0214

Obeidat, B., Sweis, R., Zyod, D., \& Alshurideh, M. (2012). The Effect of Perceived Service Quality on Customer Loyalty in Internet Service Providers in Jordan. Journal of Management Research, 4(4), $224-242$. https://doi.org/10.5296/jmr.v4i4.2130

Oluwatobi, O., \& Yemisi, B. (2014). Influence of Information Technology Competence and Demographic Characteristics on Undergraduate Student's Perception of E-Portal. International Journal of Scientific and Research Publications, 4(6).

Pallant, J. (2005). Survival Guide - A Step by Step Guide to Data Analysis Using SPSS for Windows. Chicago: Illinois: Open University Press.

Park, Y., \& Chen, J. V. (2007). Acceptance and adoption of the innovative use of smartphone. Industrial management \& Data systems, 107(9), 1349-1365. https://doi.org/10.1108/02635570710834009

Pena-Bandalaria, M. d. (2007). Impact of ICTs on Open and Distance Learning in a Developing Country Setting: The Philippine experience. The International Review of Research in Open and Distributed Learning, 8(1).

Redman, T. (2000). Data Quality: The field guide. Boston: Digital Press.

Saunders, M. N., Lewis, P., \& Thornh, A. (2009). Research Methods for Business Students. Pearson.

Sekaran, U. (2003). Research Methods for Business: A Skill-Building Approach (4th ed.). John Wiley and Sons.

Sekaran, U., \& Bougie , R. (2013). Research Methods for Business: A Skill-Building Approach (6th ed.). John Wiley and Sons.

Shaltoni, A., Khraim, H., Abuhamad, A., \& Amer, M. (2015). Exploring students' satisfaction with universities' portals in developing countries. The International Journal of Information and Learning Technology, 32(2), 82-93. doi:10.1108/IJILT-12-2012-0042

Shannak, R., Al-Zu'bi, Z., Obeidat, B., Alshurideh, M., \& Altamony, H. (2012). A Theoretical Perspective on the Relationship between Knowledge Management Systems, Customer Knowledge Management, and Firm Competitive Advantage. European Journal of Social Sciences, 23(4), 520-532.

Shannak, R., Obeidat, B., Almajali, D., \& Masa'deh, R. (2010). Information Technology Investments: A Literature Review. the 14th IBIMA Conference on Global Business Transformation through Innovation and Knowledge Management: An Academic Perspective, (pp. 1356-1368). Istanbul-Turkey.

Smith, S. M. (2001). The Four Sources of Influence on Computer Self-Efficacy. Delta PI Epsilon, 43(1), $27-39$.

Strong, D., Lee, Y., \& Wang, R. (1997). Data Quality in Context. Communications of the ACM, 40(5), $103-205$. https://doi.org/10.1145/253769.253804

Sutarso, Y., \& Suharmadi, A. (2011). Promotion of e-technology-based services: A case study of e-service quality at a University in Indonesia. International Journal of Business and Information, 6(1), 112-133.

Tate, M., Evermann, J., Hope, B., \& Barnes, S. (2007). Perceived Service Quality in a University Web Portal: Revising the E-Qual Instrument. the 40th Annual Hawaii International Conference on System Sciences (p. 
147). IEEE. https://doi.org/10.1109/hicss.2007.431

Vratskikh, I., Al-Lozi, M., \& Maqableh, M. (2016). The Impact of Emotional Intelligence on Job Performance via the Mediating Role of Job Satisfaction. International Journal of Business and Management, 11, 69-91. https://doi.org/10.5539/ijbm.v11n2p69

Wang, R. Y., \& Strong, D. M. (1996). Beyond Accuracy: What Data Quality Means to Data Consumers. Management Information Systems, 12(4), 5-33. https://doi.org/10.1080/07421222.1996.11518099

Wolfinbarger, M. F., \& Gilly, M. C. (2002). comQ: Dimensionalizing, Measuring and Predicting Quality of the E-tail Experience. Marketing Science Institute.

Yang, C. C. (2003). Establishment and Applications of the Integrated Model of Service Quality Measurement. Managing Service Quality: An International Journal, 13(4), 310-324. http://dx.doi.org/10.1108/09604520310484725

Yang, Z., Cai, S., Zhou, Z., \& Zhou, N. (2005). Development and Validation of An Instrument to Measure User Perceived Service Quality of Information Presenting Web Portals. Information \& Management, 42(4), 575-589. https://doi.org/10.1016/S0378-7206(04)00073-4

Yoo, B., \& Donthu, N. (2001). Developing a Scale to Measure the Perceived Quality of An Internet Shopping Site (SITEQUAL). Quarterly Journal of Electronic Commerce, 2(1), 31-45.

Zeithaml, V. A. (2002). Guru view. Managing Service Quality, special issue on service excellence, 12(3), 135-138.

\section{Copyrights}

Copyright for this article is retained by the author(s), with first publication rights granted to the journal.

This is an open-access article distributed under the terms and conditions of the Creative Commons Attribution license (http://creativecommons.org/licenses/by/4.0/). 